\title{
New Dissolution Method for Mesalamine Tablets and Capsules
}

\author{
Monica C. Chuong ${ }^{1,3}$, J. Mark Christensen ${ }^{2}$, and James W. Ayres ${ }^{2}$ \\ 'Department of Pharmaceutical Sciences, Massachusetts College of Pharmacy and Health \\ Sciences-Boston, 179 Longwood Ave, Boston, MA 02115 \\ ${ }^{2}$ Department of Pharmaceutical Sciences, College of Pharmacy, Oregon State University, 1601 \\ SW Jefferson Ave., Corvallis, OR 97331
}

e-mail:monica.chuong@mcphs.edu

\begin{abstract}
Dissolution methods are different for extended-release mesalamine capsules ( $\mathrm{pH} 7.5$ only) and delayed-release tablets ( $\mathrm{pH} \mathrm{1.4,6.0,} \mathrm{and} \mathrm{7.2).} \mathrm{Mesalamine} \mathrm{is} \mathrm{used} \mathrm{for} \mathrm{the} \mathrm{treatment} \mathrm{of} \mathrm{ulcerative} \mathrm{colitis.} \mathrm{The} \mathrm{USP} \mathrm{methods} \mathrm{have} \mathrm{several} \mathrm{drawbacks}$ in that they do not mimic gastrointestinal tract environments; tablets are removed from vessels to change dissolution medium; and neither method has been adopted to compare different formulations. This study proposed a method that reflects gastrointestinal transit time and $\mathrm{pH}$, is easy to conduct, and may be used to test new delayed- or extended-release formulations and compare various dosage forms.
\end{abstract}

\section{INTRODUCTION}

nflammatory bowel disease (IBD) refers to a group of diseases that principally affect the small and large intestines and is characterized by chronic inflammation of unknown etiology. The two major clinical entities are ulcerative colitis and Crohn's disease. They have several overlapping features. Crohn's disease can affect both the small and large bowels in a given patient as well as any other segment of the gastrointestinal tract (GIT). In contrast to ulcerative colitis, Crohn's disease is much less responsive to sulfasalazine. The drug is now seldom used for this condition, having been replaced by the newer 5-ASA preparation, mesalamine (1). The mesalamine dosage forms available in the FDA Orange Book are rectal enema, rectal suppository, extended-release oral capsule, and delayed-release oral tablet.

In spite of the reported success of several in vitro-in vivo correlation studies, dissolution is not a predictor of therapeutic efficiency $(2,3)$ because of the complexity of the absorption process and drug distribution to the site of action. However, it can best be described as a qualitative tool that can provide valuable information about the biological availability of a drug product. The USP dissolution methods (4) are different for extended-release mesalamine capsules (performed at $\mathrm{pH} 7.5$ only) and delayed-release tablets (performed at $\mathrm{pH} 1.4$ for $2 \mathrm{~h}, \mathrm{pH}$ 6.0 for $1 \mathrm{~h}$, and finally at $\mathrm{pH}$ 7.2). GIT transit times (Table 1) are not reflected in the USP methods for extended-release mesalamine capsules. Additional drawbacks include (1) food effects on drug release are not considered, (2) tablets are removed from vessels to change dissolution medium, and (3) neither method has been adopted to compare different formulations together. Thus, this study was aimed

${ }^{3}$ Corresponding author. at testing one commercially available extended-release mesalamine capsule (Pentasa, 250 and $500 \mathrm{mg}$ ) and one delayed-release tablet (Asacol, $400 \mathrm{mg}$ ) using the USP dissolution methods to identify the shortcomings of each methodology. Pentasa beads have a coating of ethylcellulose, while Asacol tablets are coated with Eudragit S. Also suggested is a new dissolution method that reflects gastrointestinal transit times (5) and could be used to compare various mesalamine solid dosage forms simultaneously.

\section{MATERIALS AND METHODS \\ Reagents and Standards}

Mesalamine was gift of TEVA Pharmaceuticals. Hydrochloric acid, sodium hydroxide, and potassium phosphate were ordered from Fisher Scientific (Fair Lawn, NJ).

\section{Commercial Capsules and Tablets}

Pentasa (mesalamine controlled-release capsules, 250 and $500 \mathrm{mg}$ ) and Asacol (mesalamine delayed-release tablets, $400 \mathrm{mg}$ ) were obtained from OSU Campus Pharmacy.

\section{USP Dissolution Method for Extended-Release Mesalamine Capsules}

Phosphate buffer $(0.05 \mathrm{M})$ at $\mathrm{pH} 7.5$ was prepared by dissolving $6.8 \mathrm{~g}$ of monobasic potassium phosphate and 1 $\mathrm{g}$ of sodium hydroxide in water to make $1000 \mathrm{~mL}$ of solution and adjusting the $\mathrm{pH}$ to $7.5 \pm 0.05$ with $1.0 \mathrm{~N}$ sodium hydroxide.

Pentasa in vitro dissolution study was accomplished using a USP Apparatus II. Each vessel was filled with 900 $\mathrm{mL}$ of preheated $\left(37^{\circ} \mathrm{C}\right)$ deaerated $0.05 \mathrm{M}$ phosphate buffer at $\mathrm{pH} 7.5$ as receptor medium. The paddle rotation speed was set at $100 \mathrm{rpm}$. The water bath was maintained 
Table 1. Comparison of Different Parts of the Gastrointestinal Tract ${ }^{a}$

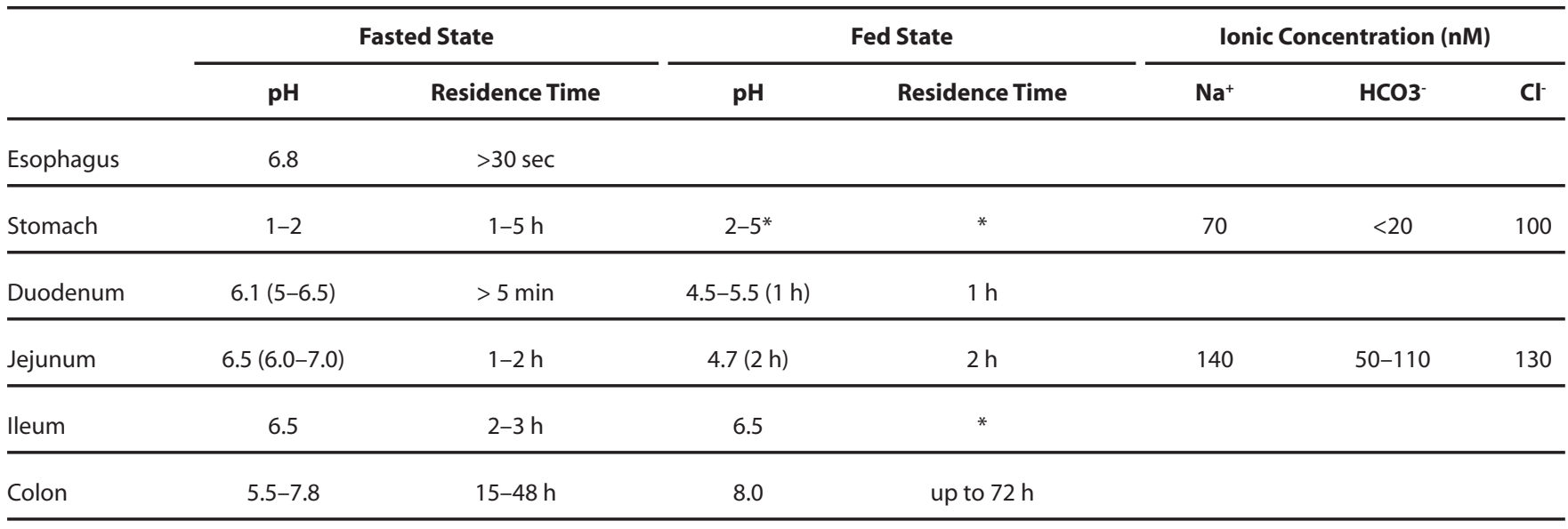

${ }^{a}$ Adapted with permission from refs 8-10.

* Dependent on volume, $\mathrm{pH}$, and buffer capacity of the food.

at $37.0 \pm 0.5^{\circ} \mathrm{C}$ to mimic intestinal temperature. Four milliliters of solution from each vessel was collected at each sampling time. The sample schedule given by USP 28/NF 23 was 1, 2, 4, and 8 h. Equivalent amounts of fresh medium were not replenished after each sample withdrawal, but a correction factor was added during data analysis. Samples of $1 \mathrm{~mL}$ were diluted 10 -fold and then assayed in a Beckman DU640 Spectrophotometer (Beckman Coulter, Fullerton, CA) at 330 nm.

\section{USP Dissolution Methods for Delayed-Release Mesalamine Tablets}

The USP method for mesalamine delayed-release tablets is divided into three stages, an acidic stage and buffer stages I and II, to mimic gastrointestinal $\mathrm{pH}$ environments and transit times. Asacol $(400 \mathrm{mg})$ tablets were tested. For the acidic stage, $500 \mathrm{~mL}$ of $0.1 \mathrm{~N} \mathrm{HCl}$ was prepared and added to each dissolution vessel. Testing was performed using USP dissolution Apparatus II (paddle method) at $100 \mathrm{rpm}$ and $37.5 \pm 0.5^{\circ} \mathrm{C}$. Four milliliters of solution from each vessel was collected after two hours of operation. Tablets were then recovered from the vessel after draining the medium from the flask. Test tablets were blotted dry before transferring into buffer stage I medium.

Nine hundred milliliters of phosphate buffer at pH 6.0 was prepared based on buffer stage I medium according to the Solutions chapter in the USP 30/NF 25. In buffer stage I, dissolution was resumed at $100 \mathrm{rpm}$ for $1 \mathrm{~h}$. Then, after a sample was withdrawn, $50 \mathrm{~mL}$ of dissolution medium of buffer stage I was removed and replaced with $47 \mathrm{~mL}$ of $0.6 \mathrm{M} \mathrm{NaOH}$ to adjust $\mathrm{pH}$ from 6.0 to 7.2 as buffer stage II. Dissolution stirring rate was changed from 100 rpm to $50 \mathrm{rpm}$ to run for $90 \mathrm{~min}$.

\section{Lab-Proposed Dissolution Protocols to Test Mesalamine Capsules and Tablets Simultaneously \\ The USP dissolution methods are different for extended-release mesalamine capsules ( $\mathrm{pH} 7.5$ only)}

and delayed-release tablets ( $\mathrm{pH} 1.4,6.0$, and 7.2). The consideration of true residence time in different parts of the gut is not implemented. Thus, we propose a method with the following merits: (1) It reflects gastrointestinal transit times, which are not present in the USP method for mesalamine capsules. (2) It does not require the removal of tablets or drug beads from dissolution vessels to change media. Finally, (3) this method also allows comparison of different formulations.

Brand-name mesalamine tablets (Asacol, $400 \mathrm{mg}$ ) and capsules (Pentasa, 250 and $500 \mathrm{mg}$ ) were tested by two separate methods (a 12-h method and a 14-h method) with USP dissolution Apparatus II with both methods following a three-step process. The first step was in gastric fluid (acidic dissolution stage, $500 \mathrm{~mL}$ of $2 \mathrm{~g} / \mathrm{L} \mathrm{NaCl}, \mathrm{pH}$ adjusted to 1.4 with $\mathrm{HCl}$ ) for $2 \mathrm{~h}$. Samples were collected at the end of the acidic dissolution phase. In step 2 (buffer stage I), $245 \mathrm{~mL}$ of $0.09 \mathrm{M} \mathrm{Na}_{3} \mathrm{PO}_{4} \cdot 12 \mathrm{H}_{2} \mathrm{O}$ was added to bring the dissolution medium $\mathrm{pH}$ from 1.4 to 6.0 to simulate small intestinal fluid. Dissolution was continued at $100 \mathrm{rpm}$ for 2 or $4 \mathrm{~h}$. Step 3 (buffer stage 2) of dissolution was in simulated large intestinal fluid (by addition of $100 \mathrm{~mL}$ of $0.3 \mathrm{M} \mathrm{NaOH}$ or $87 \mathrm{~mL}$ of $0.05 \mathrm{M}$ $\mathrm{Na}_{3} \mathrm{PO}_{4} \cdot 12 \mathrm{H}_{2} \mathrm{O}$ to raise medium $\mathrm{pH}$ to 7.3 ) for an additional $8 \mathrm{~h}$ of dissolution testing. By doing so, tablets or capsule beads did not have to leave the dissolution vessel during the test. Total dissolution time was 12 or $14 \mathrm{~h}$. The sampling schedule for the 12-h method was 1, 2, 3, 4, 4.5, 5, 6,8 , and $12 \mathrm{~h}$ ( 9 sampling points, 2 -h residence time at $\mathrm{pH}$ 6.0), and the sampling schedule for the 14-h method was $0,1,2,2.5,3,4,5,6,6.5,7,8,10$, and $14 \mathrm{~h}$ (13 sampling points, 4-h residence time at $\mathrm{pH} 6.0$ ). After dissolution testing, the concentrations were quantified using a UV spectrophotometer. The cumulative amount of drug release at each sampling point was computed for both the extended-release capsules, Pentasa (250 and $500 \mathrm{mg}$ ), and delayed-released tablets, Asacol $(400 \mathrm{mg})$. The release profiles of Asacol and Pentasa were plotted together as 
the percent of drug released versus time. There should be no more than $1 \%$ of mesalamine released at the end of the acidic stage and buffer stage I dissolution test according to the USP criteria for delayed-release tablets. For dissolution testing of mesalamine oral products, we also suggest running the test at $\mathrm{pH} 2.75$ for up to $5 \mathrm{~h}$ to mimic the residence time of the oral product in the fed state in the stomach.

\section{Examination of Fasted and Fed Gastric pH Effects of Mesalamine Capsules}

After finding that the Pentasa capsule was sensitive to low $\mathrm{pH}$ in our proposed method, we studied the release behavior of Pentasa in five different simulated gastric fluids based on the USP methods. Five hundred milliliter aliquots of simulated gastric fluid at $\mathrm{pH}$ 1.2, 1.4, 1.6, 2.0, and 2.75 were prepared using $0.1 \mathrm{~N} \mathrm{HCl}$ with addition of $0.2 \mathrm{M} \mathrm{HCl}$ or $\mathrm{NaOH}$ to produce the designated $\mathrm{pH}$. The maximum concentration of mesalamine in this dissolution test was $1 \mathrm{mg} / \mathrm{mL}$, which is below the observed maximum concentration reported for these $\mathrm{pH}$ values (6).

\section{Behavior of Eudragit S Coat of Asacol in Intestinal pH}

Suspecting that Eudragit $\mathrm{S}$ might respond differently in intestinal $\mathrm{pH}$ whether an Asacol tablet has been in acidic $\mathrm{pH}$ or not, we tested the delayed-release tablet in $900 \mathrm{~mL}$ of dissolution medium at each $\mathrm{pH}$ of $6.5,6.8,7.0,7.2$, or 7.5 alone for up to $5 \mathrm{~h}$. We also tested it through the entire range of simulated $\mathrm{GIT} \mathrm{pH}, 500 \mathrm{~mL}$ in gastric phase, and $900 \mathrm{~mL}$ in intestinal phases. Different $\mathrm{pH}$ levels were selected for the gastric and upper small intestine to represent fasted and fed states. $\mathrm{A} \mathrm{pH}$ of 6.5 was chosen for the lower small intestine, while $\mathrm{pH} 7.2$ was selected to represent the colonic environmental $\mathrm{pH}$. The five media preparations used in this study were:

(1) $\mathrm{pH} 1.4$ for $12 \mathrm{~h}, \mathrm{pH} 4.5$ for $3 \mathrm{~h}, \mathrm{pH} 6.5$ for $1.5 \mathrm{~h}$, and $\mathrm{pH} 7.2$ for $2 \mathrm{~h}$.

(2) $\mathrm{pH} 1.75$ for $12 \mathrm{~h}, \mathrm{pH} 5.0$ for $3 \mathrm{~h}, \mathrm{pH} 6.5$ for $1.5 \mathrm{~h}$, and $\mathrm{pH} 7.2$ for $2 \mathrm{~h}$.

(3) $\mathrm{pH} 2.0$ for $12 \mathrm{~h}, \mathrm{pH} 5.5$ for $3 \mathrm{~h}, \mathrm{pH} 6.5$ for $1.5 \mathrm{~h}$, and $\mathrm{pH} 7.2$ for $2 \mathrm{~h}$.

(4) $\mathrm{pH} 2.25$ for $12 \mathrm{~h}, \mathrm{pH} 6.0$ for $3 \mathrm{~h}, \mathrm{pH} 6.5$ for $1.5 \mathrm{~h}$, and $\mathrm{pH} 7.2$ for $2 \mathrm{~h}$.

(5) $\mathrm{pH} 2.75$ for $12 \mathrm{~h}$ and $\mathrm{pH} 6.5$ for $3 \mathrm{~h}$.

\section{Assays}

Mesalamine standard solutions at different $\mathrm{pH}$ levels were scanned using an ultraviolet/visible spectrophotometer. The assay wavelengths used to quantify mesalamine are as follows:
$302 \mathrm{~nm}$
$300 \mathrm{~nm}$
$\mathrm{pH} 1.2,1.4,1.6$
$297 \mathrm{~nm}$
$\mathrm{pH} 1.75,2.0$
$326 \mathrm{~nm}$
$\mathrm{pH} 2.75,4.5,5.0$
$330 \mathrm{~nm}$
$\mathrm{pH} 5.5$
$\mathrm{pH} 6.0,6.5,6.8,7.0,7.2,7.5$

The calibration curves were constructed. Under the reported conditions, we found that the linear ranges of mesalamine calibration curves extended from 1 to $100 \mu \mathrm{g} /$ $\mathrm{mL}$ (Figure 1). One milliliter of medium was taken from each sample collected during dissolution experiments, diluted 10-fold, and assayed in a Beckman DU640 Spectrophotometer (Beckman Coulter, Fullerton, CA) at the wavelengths mentioned above according to the $\mathrm{pH}$ of the dissolution medium. Concentrations were determined from standard curves prepared in the appropriate gastric $\mathrm{pH}$ or buffer $\mathrm{pH}$ medium. After concentrations were quantified using a UV spectrophotometer, the cumulative amount and percentage of drug release at each sampling schedule was computed (Figure 1). Release profiles were then plotted as the cumulative percent of drug released versus time.

(A)

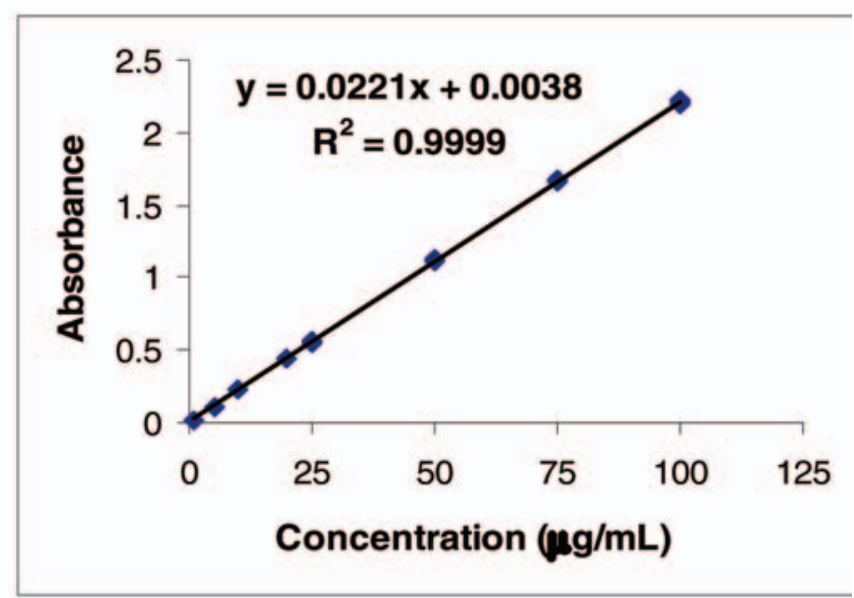

(B)

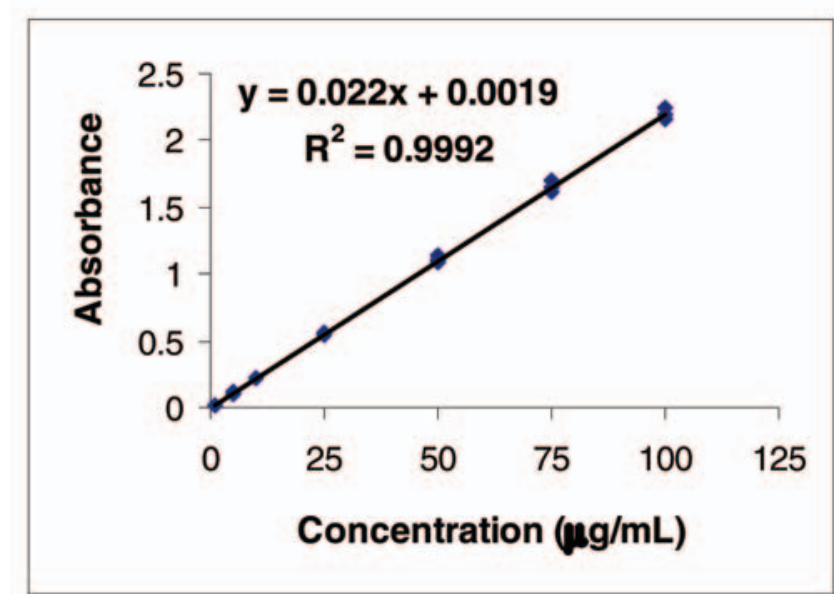

Figure 1. Mesalamine standard curves in $(A)$ simulated gastric fluid $(0.1 \mathrm{~N} \mathrm{HCl})$ and $(B)$ simulated small intestine fluid and large intestinal fluid (pH6.0-7.5 phosphate buffer). 


\section{RESULTS}

USP Method for Extended-Release Mesalamine Capsules and Delayed-Release Mesalamine Tablets

Using the USP dissolution protocols to evaluate extended-release capsules, Pentasa, and delayed-released tablets, Asacol, we plotted the percent of drug released versus time for these two formulations. The release profiles for both strengths of Pentasa capsules lasted for $8 \mathrm{~h}$ while that of Asacol tablets was $4.5 \mathrm{~h}$. Not only were the dissolution profiles different for the two commercial products, the shapes of the release profiles were also different as expected (Figure 2). This difference was not from the release behavior alone, but was also due to different dissolution protocols. Dissolution testing at only $\mathrm{pH} 7.5$ is not reflective of the gastrointestinal tract. In addition, a 2-D plot cannot reflect the dissolution behavior in different $\mathrm{pH}$ levels. Thus, plotting percent of release versus time as a two-dimensional plot did not yield any meaningful interpretation allowing appraisal of which formulation performed superiorly. Using a threedimensional computer software program to plot $\mathrm{pH}$ and cumulative percent of release against time may be helpful. However, the illustrative information presented in a 3-D chart would be more complex for interpretation.

\section{Lab-Proposed Dissolution Protocols to Test} Mesalamine Capsules and Tablets Simultaneously

Two different dissolution methods were proposed by our lab to compare mesalamine extended-release capsules and delayed-release tablets, 12-h dissolution with nine sampling points and 14-h dissolution with 13 sampling points. The difference between the 12-h and 14-h dissolution methods is based upon the length of time the dosage form may reside in the small intestine. The 12-h method assumes a $2 \mathrm{~h}$ residence time while the 14-h method assumes a 4-h residence time.

\section{Mesalamine Tablets}

With the new dissolution method proposed by our lab, delayed-released tablets did not release drug $(<1 \%)$ until

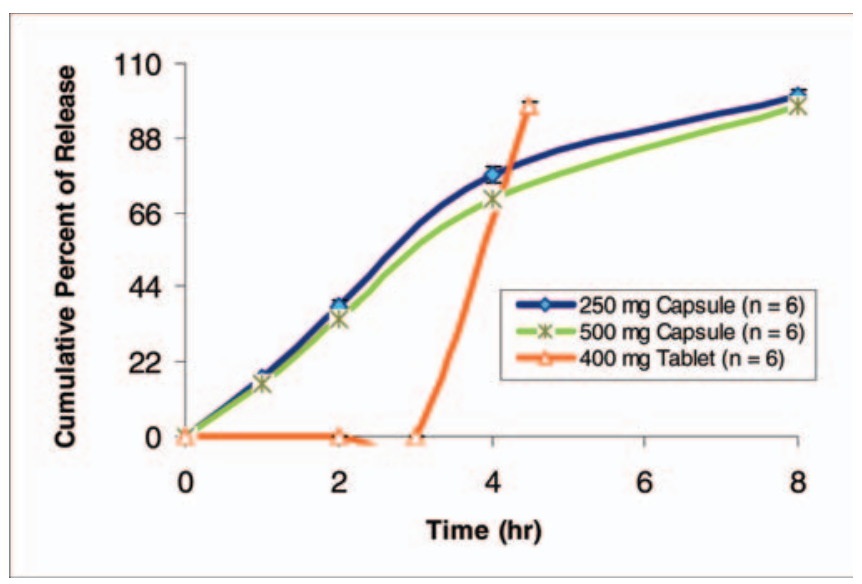

Figure 2. Mesalamine dissolution profiles using the USP methods.

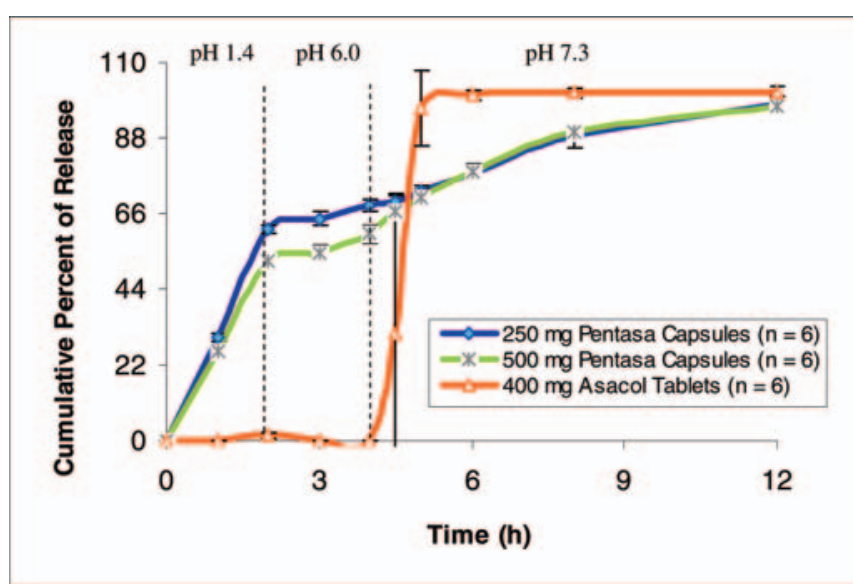

Figure 3. Mesalamine dissolution profiles in simulated fasted state using the proposed nine sampling point method.

reaching buffer stage II, $\mathrm{pH} 7.3$, whether they were tested with the 12-h or 14-h method. There was a high variability in drug release within the first $0.5 \mathrm{~h}$ to $1 \mathrm{~h}$ after the $\mathrm{pH}$ was adjusted to 7.3 (Figure 3). In the 12-h dissolution, 9 sampling point method, in buffer stage II the release was $31.0 \pm 41.0 \%$ at $0.5 \mathrm{~h}$ and $96.6 \pm 10.9 \%$ at $1.0 \mathrm{~h}(n=6$, Fig. 3). Release was completed (100.6 $\pm 1.3 \%$ ) after the tablets were in buffer stage II for $90 \mathrm{~min}$. In the 14-h, 13-point method, the release was $24.6 \pm 34.2 \%$ at $0.5 \mathrm{~h}$ and $66.4 \pm 131.7 \%$ at $1.0 \mathrm{~h}(n=6)$ after $\mathrm{pH}$ was adjusted to 7.3. Release was $93.2 \pm 7.9 \%$ after the tablets were in buffer stage II for $2 \mathrm{~h}$ and $99.6 \pm 2.7 \%$ at $4 \mathrm{~h}(n=6$, Fig. 4$)$.

\section{Mesalamine Capsules}

Twelve-hour dissolution, nine sampling point method

The extended-release capsules started to release drug in the acidic dissolution stage as early as $1 \mathrm{~h} \mathrm{(30.1 \pm 0.6 \%}$ for $250 \mathrm{mg}$ and $26.1 \pm 0.6 \%$ for $500 \mathrm{mg}$ ). In the $12-\mathrm{h}, 9$ sample point dissolution method, the $250-\mathrm{mg}$ capsules released $61.6 \pm 0.9 \%$ of mesalamine, and $500-\mathrm{mg}$ capsules released $52.1 \pm 1.1 \%$ at the end of buffer stage I $(2 \mathrm{~h}$ at $\mathrm{pH} 6.0$ ). The $250-\mathrm{mg}$ capsules released $68.3 \pm 2.0 \%$, and 500-mg capsules $60.0 \pm 2.2 \%$ after $2 \mathrm{~h}$ in buffer stage II $(\mathrm{pH} 7.3)$ and $97.7 \pm 3.2 \%$ and $97.1 \pm 1.8 \%$ after $4 \mathrm{~h}$ ( $n=6$, Figure 3).

Fourteen-hour dissolution, thirteen sampling point method

In this method, dosage forms were in gastric $\mathrm{pH}$ for $2 \mathrm{~h}$, small intestinal $\mathrm{pH}$ for $4 \mathrm{~h}$, and large intestine $\mathrm{pH}$ for $8 \mathrm{~h}$. The six 250-mg extended-release capsules released $49.9 \pm$ $5.0 \%$, and six 500-mg capsules released $47.0 \pm 3.7 \%$ at the end of $2 \mathrm{~h}$ in acidic stage. The $250-\mathrm{mg}$ extended-release capsules released $61.5 \pm 3.5 \%$, and $500 \mathrm{mg}$ released $65.3 \pm 3.8 \%$ at the end of $4 \mathrm{~h}$ after the dissolution media were changed to buffer stage I ( $\mathrm{pH}$ 6.0). Both strengths released mesalamine completely after $12 \mathrm{~h}$; the 250 -mg capsules released $95.6 \pm 1.3 \%$ and $500-\mathrm{mg}$ released 


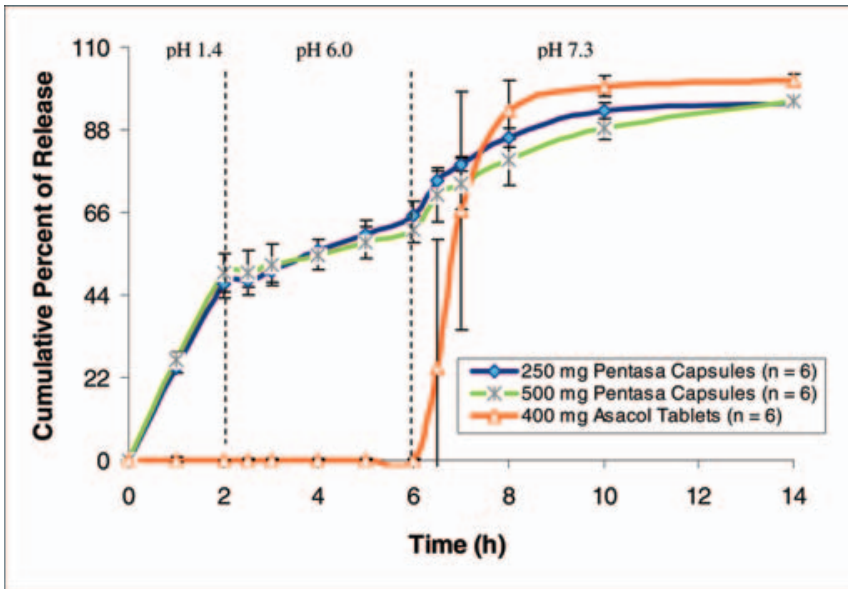

Figure 4. Mesalamine dissolution profiles in simulated fasted state using the proposed 13 sampling point method.

$95.2 \pm 1.8 \%$ after being in buffer stage II $(\mathrm{pH} 7.3)$ for $8 \mathrm{~h}$ (Figure 4).

Release of mesalamine capsules in the proposed method at $\mathrm{pH} 2.75$ to examine fed state in gastric phase

After finding that mesalamine extended-release capsules had high percentage of release at $\mathrm{pH} 1.4$ in $2 \mathrm{~h}$, we tested both 250- and 500-mg capsules at $\mathrm{pH} 2.75$ up to $5 \mathrm{~h}$ to mimic stomach fed condition. The mesalamine release was $4.0 \pm 0.1 \%$ at $1 h, 8.7 \pm 0.1 \%$ at $2 h$, and $22.7 \pm$ $0.5 \% 5 \mathrm{~h}(n=3$, Figure 5$)$. These results were quite different from the mesalamine release in the acidic dissolution stage of the 12-h method (approximately $60 \%$ in $2 \mathrm{~h}$, Figure 2) and that of the 14-h method (100\% in 2 h, Figure 4). Data suggest that these dosage formulations are quite sensitive to small changes in an acid medium.

\section{Examination of Fasted and Fed Gastric pH Effects of} Mesalamine Capsules Based on Compendial Methods

After finding that Pentasa capsules were sensitive to low $\mathrm{pH}$ in our proposed method, we further studied the

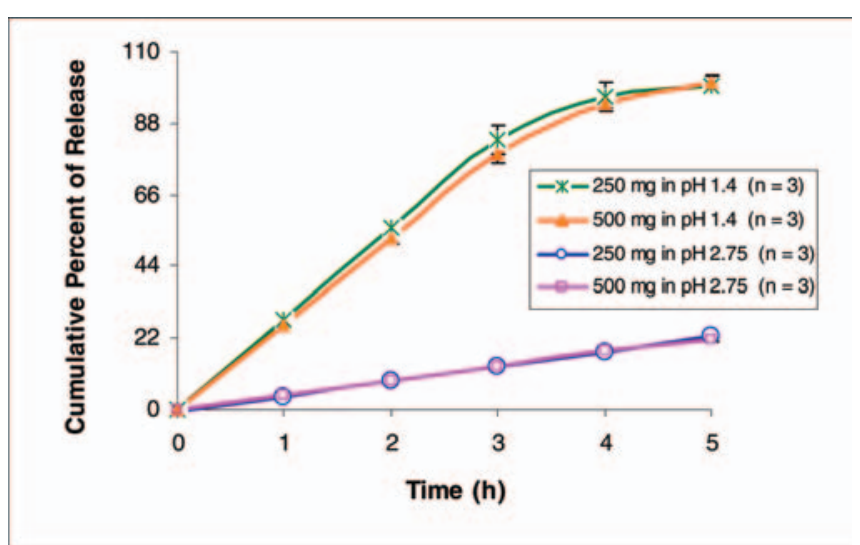

Figure 5. Dissolution profiles of extended-release mesalamine capsules 250 and $500 \mathrm{mg}$ at $\mathrm{pH} 1.4$ and $\mathrm{pH} 2.75$ using the proposed method.

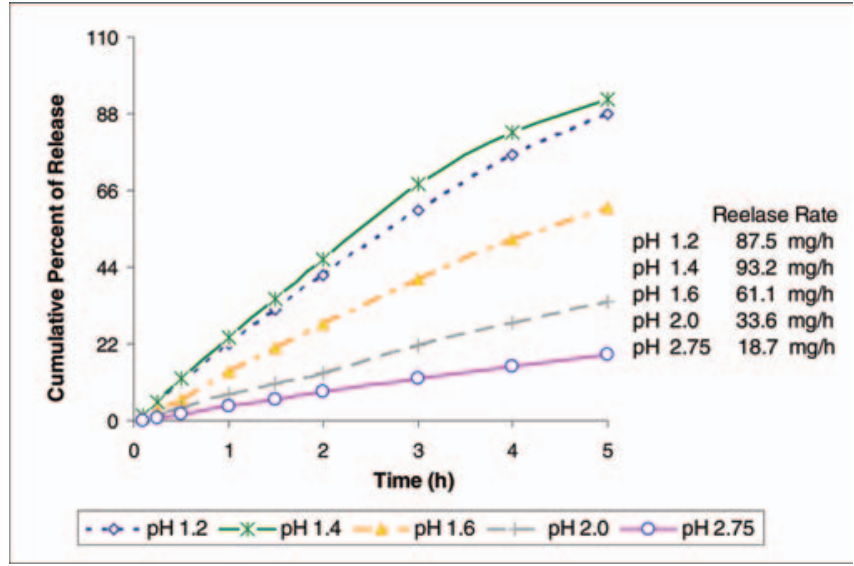

Figure 6. Dissolution profiles of Pentasa $500 \mathrm{mg}$ at various gastric $\mathrm{pH}$ levels of $1.2,1.4,1.6,2.0$, and 2.75 up to $5 \mathrm{~h}$ using the USP mesalamine acidic stage preparation.

release behavior of 500-mg Pentasa capsules in five different simulated gastric fluids, $\mathrm{pH} 1.2,1.4,1.6,2.0$, and 2.75. The release was $\mathrm{pH}$-dependent (Figure 6).

When the cumulative percent of release was plotted against time in hours, the mesalamine dissolution profile exhibited a linear relationship in $\mathrm{pH} 1.6,2.0$, and 2.75 media, but concaved slightly at $3 \mathrm{~h}$ in $\mathrm{pH} 1.2$ and 1.4. The slope of the release profile was taken as the release rate. The percent of release was $41.7 \%$ in $2 \mathrm{~h}$ and $88.0 \%$ in $5 \mathrm{~h}$ at $\mathrm{pH} 1.2,46.1 \%$ in $2 \mathrm{~h}$ and $92.2 \%$ in $5 \mathrm{~h}$ at $\mathrm{pH} 1.4,27.7 \%$ in $2 \mathrm{~h}$ and $61.20 \%$ in $5 \mathrm{~h}$ at $\mathrm{pH} 1.6,13.5 \%$ in $2 \mathrm{~h}$ and $34.2 \%$ in $5 \mathrm{~h}$ at $\mathrm{pH} 2.0,8.2 \%$ in $2 \mathrm{~h}$ and $19.0 \%$ in $5 \mathrm{~h}$ at $\mathrm{pH} 2.75$. Among the five tested $\mathrm{pH}$ levels, the mesalamine release rate was the highest at $\mathrm{pH}$ 1.4. They were $87.5 \mathrm{mg} / \mathrm{h}$ at $\mathrm{pH}$ $1.2,93.2 \mathrm{mg} / \mathrm{h}$ at $\mathrm{pH} 1.4,61.1 \mathrm{mg} / \mathrm{h}$ at $\mathrm{pH} 1.6,33.6 \mathrm{mg} / \mathrm{h}$ at $\mathrm{pH} 2.0$, and $18.7 \mathrm{mg} / \mathrm{h}$ at $\mathrm{pH} 2.75$ (Figure 6).

\section{Examination of Dissolution Behaviors of Eudragit $\mathbf{S}$ Coat in Intestinal pH Dissolution of Asacol Tablet in Intestinal pH Alone}

No mesalamine was released in $5 \mathrm{~h}$ when an Asacol tablet was placed in $900 \mathrm{~mL}$ of $\mathrm{pH} 6.5$ dissolution medium with paddle method at $100 \mathrm{rpm}$. At pH 6.8, no release was noted in $2 \mathrm{~h}$ and $96.2 \%$ in $5 \mathrm{~h}$. At pH 7.0, no mesalamine was released in $1 \mathrm{~h}, 87.3 \%$ in $2 \mathrm{~h}$, and $97.7 \%$ in $5 \mathrm{~h}$. At pH $7.2,16.7 \%$ mesalamine was released in $1 \mathrm{~h}, 90.0 \%$ mesalamine was released in $2 \mathrm{~h}$, and $98.5 \%$ in $5 \mathrm{~h}$, and at $\mathrm{pH} 7.5$, $62.4 \%$ of drug released in $1 \mathrm{~h}, 92.9 \%$ in $2 \mathrm{~h}$, and $100.8 \%$ in $5 \mathrm{~h}$ (Figure 7).

\section{Dissolution of Asacol Tablet over the Range of GIT pH}

There was no observed mesalamine release in $12 \mathrm{~h}$ whether the tablet was at $\mathrm{pH} 1.4,1.75,2.0,2.25$, or 2.75 (Figure 8). The first tablet did not dissolve while at $\mathrm{pH} 1.4$ for $12 \mathrm{~h}$ and $\mathrm{pH} 4.5$ for $3 \mathrm{~h}$, but $39.5 \%$ dissolved at the end of $1.5 \mathrm{~h}$ at $\mathrm{pH} 6.5$ at $100 \mathrm{rpm}$. It was found to have total of $77.1 \%$ dissolved when continued at $\mathrm{pH} 7.2$ at $50 \mathrm{rpm}$ for 


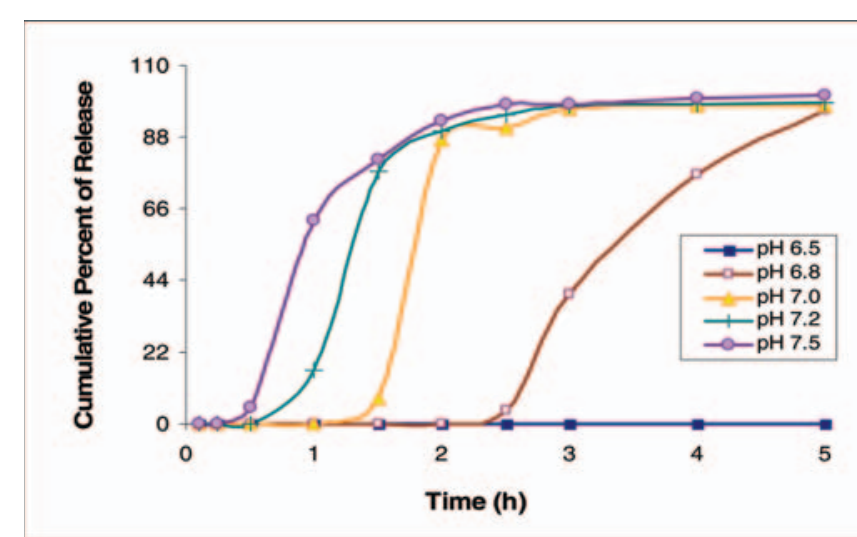

Figure 7. Dissolution profiles of Asacol $400 \mathrm{mg}$ at various intestinal $\mathrm{pH}$ levels using the USP buffer stage preparation for mesalamine delayed-release tablets.

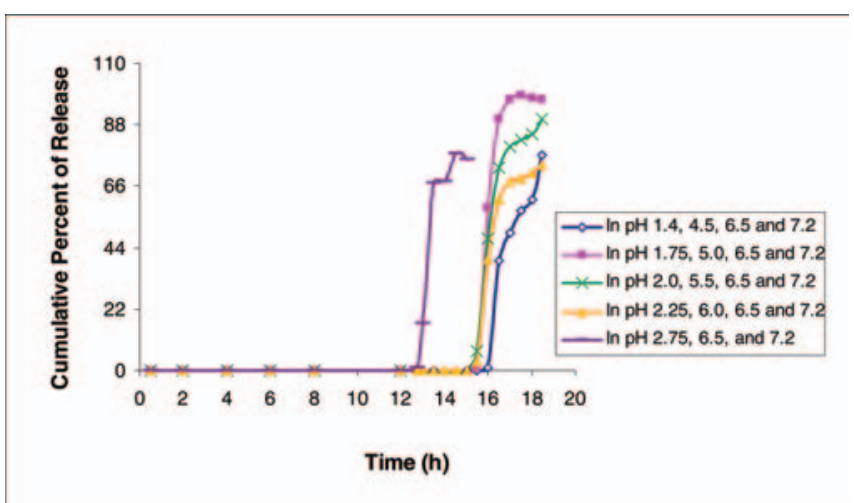

Figure 8. Asacol dissolution profile over the range of simulated GIT pH at fed and fasted states using the USP method for mesalamine delayed-release tablets.

another $2 \mathrm{~h}$. The second tablet did not dissolve while at $\mathrm{pH} 1.75$ for $12 \mathrm{~h}$ and $\mathrm{pH} 5.0$ for $3 \mathrm{~h}$, but $90.1 \%$ dissolved at the end of $1.5 \mathrm{~h}$ at $\mathrm{pH} 6.5$ at $100 \mathrm{rpm}$. It was found to have $97.1 \%$ dissolved when continued at $\mathrm{pH} 7.2$ at $50 \mathrm{rpm}$ for anther $2 \mathrm{~h}$.

The third tablet did not dissolve while at $\mathrm{pH} 2.0$ for $12 \mathrm{~h}$ and $\mathrm{pH} 5.5$ for $3 \mathrm{~h}$, but $72.8 \%$ dissolved at the end of $1.5 \mathrm{~h}$ at $\mathrm{pH} 6.5$ at $100 \mathrm{rpm}$. It was found to have A total of $89.9 \%$ dissolved when continued at $\mathrm{pH} 7.2$ at $50 \mathrm{rpm}$ for another $2 \mathrm{~h}$. The fourth tablet did not dissolve while at $\mathrm{pH} 2.25$ for $12 \mathrm{~h}$ and $\mathrm{pH} 6.0$ for $3 \mathrm{~h}$, but $61.2 \%$ dissolved at the end of $1.5 \mathrm{~h}$ at $\mathrm{pH} 6.5$ at $100 \mathrm{rpm}$. It was found to have $73.9 \%$ dissolved when continued at $\mathrm{pH} 7.2$ at $50 \mathrm{rpm}$ for another $2 \mathrm{~h}$.

The fifth tablet did not dissolve while at $\mathrm{pH} 2.75$ for $12 \mathrm{~h}$, but $75.7 \%$ dissolved at the end of $3 \mathrm{~h}$ at $\mathrm{pH} 6.5$ at $100 \mathrm{rpm}$. The dissolution of this tablet was not continued to $\mathrm{pH} 7.2$ since the coat was removed from the dissolution medium to be photographed. The Eudragit S coat had developed a slit when the tablets were at $\mathrm{pH} 6.5$, but the coats did not dissolve. Since it is known that Eudragit $\mathrm{S}$ is soluble at a $\mathrm{pH}$ greater than 7.0, the experiment with this tablet was terminated at $\mathrm{pH} 6.5$.

\section{DISCUSSION}

The two pharmaceutical products responded quite differently in either the USP method or the proposed methods due to different formulation excipients. The delayed-release tablets are coated with Eudragit S, while the extended-release capsule beads are coated with cellulose derivatives. Using the USP dissolution protocols to evaluate extended-release capsules, Pentasa, and delayed-released tablets, Asacol, we found that the release profiles of these two formulations cannot be plotted together in a meaningful manner, because a twodimensional plot (percent of release vs. time) does not include the information about the dissolution behavior at different $\mathrm{pH}$ levels.

The additional disadvantages of the USP methods can be described as follows.

(1) The one-stage method for extended-release capsules, which were only tested at $\mathrm{pH} 7.5$, does not reflect the GIT transit process and $\mathrm{pH}$ effects.

(2) Tablets in the three-stage method must be removed from the dissolution vessels between the acid stage and buffer stage 1. This step prolongs experimental time and may introduce errors.

(3) The three-stage method is difficult to apply to extended-release capsules since beads start to release mesalamine within $10 \mathrm{~min}$. Discarding the remaining medium at the end of the acidic stage after an aliquot of the fluid is withdrawn may cause loss of some tested beads and lead to different amounts of medium being drained.

(4) Plotting percent of release versus time as a two-dimensional plot did not yield meaningful interpretation of the data from the two dosage forms for comparison if the USP methods are to be used. Using a three-dimensional computer software program to plot $\mathrm{pH}$ and cumulative percent of release against time should be considered. However, the proposed method allows the experimental data to be presented in a 2-D plot since all mesalamine dosage forms are tested in the sequence at three suggested $\mathrm{pH}$ levels and for the same duration in each medium. Large $Y$-error bars were present for Asacol tablets following transfer into $\mathrm{pH} 7.3$ for $30 \mathrm{~min}$ and $1 \mathrm{~h}$, but these in vitro differences are not important with respect to clinical care. A two-dimension plot is sufficient to compare the release behaviors among formulations. The tested $\mathrm{pH}$ levels may be easily labeled in a 2-D figure (Figures 3 and 4).

The merits of the proposed method are (1) it is easier than the USP three-stage method since formulations are not removed from dissolution vessels between the 
acid stage and buffer stage 1 and (2) it can be used to compare release performances of delayed-release and extended-release formulations simultaneously. The addition of $\mathrm{Na}_{3} \mathrm{PO}_{4} \cdot 12 \mathrm{H}_{2} \mathrm{O}$ to increase the $\mathrm{pH}$ from 1.4 to 6.0 and from 6.0 to 7.3 increases the ionic strength (6) of the dissolution media of our proposed method and may affect dissolution of mesalamine differently than using the dissolution media in the USP monograph for mesalamine solid dosage forms. Our methods showed that using $\mathrm{Na}_{3} \mathrm{PO}_{4} \cdot 12 \mathrm{H}_{2} \mathrm{O}$ does not affect the release of mesalamine from delayed-release tablets, Asacol, as they do not release drug until reaching $\mathrm{pH}$ 7.3. To examine whether adjusting $\mathrm{pH}$ with $\mathrm{Na}_{3} \mathrm{PO}_{4} \cdot 12 \mathrm{H}_{2} \mathrm{O}$ affects mesalamine extended-release capsules, we used a different buffer medium concentration and different a volume of $\mathrm{Na}_{3} \mathrm{PO}_{4} \cdot 12 \mathrm{H}_{2} \mathrm{O}$ to bring the $\mathrm{pH}$ from 1.4 to 6.0. We also replaced $87 \mathrm{~mL}$ of $0.05 \mathrm{M} \mathrm{Na}_{3} \mathrm{PO}_{4} \cdot 12 \mathrm{H}_{2} \mathrm{O}$ with $100 \mathrm{~mL}$ of $0.3 \mathrm{M} \mathrm{NaOH}$ to adjust pH from 6.0 to 7.3 and did not find any significant difference in mesalamine release performance. Whether the dissolution test performed on the dosage form was conducted using the 9-point $12 \mathrm{~h}$ or 13-point $14 \mathrm{~h}$ proposed method, it yielded similar dissolution profiles. These buffer preparations were only tested in Pentasa 250-mg and 500-mg extended-release capsules and Asacol 400-mg delayed-release tablet. Luckily, other than Pentasa and Asacol, there is only one other oral product of mesalamine in the United States that was not tested by our proposed buffer preparations, which is the newly marketed Lialda, a delayed-release tablet, by Shire Laboratories (the manufacturer of Pentasa) .

In the Merck Index (11), mesalamine is listed as soluble in $\mathrm{HCl}$, slightly soluble in cold water and alcohol, and more soluble in hot water. The solubility-pH profile increases at $\mathrm{pH}<2.0$ and $\mathrm{pH}>5.5$ and decreases from $\mathrm{pH} 2.0$ to 5.5. The flux data were consistent with the solubility data from $\mathrm{pH} 1.0$ to 5.5. The flux increased and plateaued at $\mathrm{pH}$ values of 5.5 to 7.0 and was dependent on the bulk buffer concentration (6). The profiles at pH 1.4 (Figure 4) and at pH 1.2 and 1.4 (Figure 6) indicate that sink conditions were not quite maintained after Pentasa capsule had been in $500 \mathrm{~mL}$ dissolution medium for $3 \mathrm{~h}$. The highest release rate was noted at $\mathrm{pH}$ 1.4. The comparison of $\mathrm{pH} 1.4$ and 2.75 between Figures 4 and 5 suggests that the acidic stage of the proposed method yields similar results to that of the USP method.

It is known that Eudragit $\mathrm{S}$ is soluble at $\mathrm{pH}>7.0$ (7). But in the present study, we found that Eudragit $\mathrm{S}$ started to dissolve after being at $\mathrm{pH} 6.8$ for $2.5 \mathrm{~h}$, at $\mathrm{pH} 7.0$ for $1.5 \mathrm{~h}$, at $\mathrm{pH} 7.2$ for $1 \mathrm{~h}$, and at $\mathrm{pH} 7.5$ for $0.5 \mathrm{~h}$. We also noted that the Eudragit $\mathrm{S}$ coat of an Asacol tablet developed a slit when it was allowed to sit in $\mathrm{pH} 6.5$ media for an additional $2 \mathrm{~h}$ after the dissolution test was terminated at $5 \mathrm{~h}$, for a total of $7 \mathrm{~h}$ at $\mathrm{pH} 6.5$ (data not shown).

However, Eudragit $\mathrm{S}$ coating behaves differently when an Asacol tablet was placed in gastric $\mathrm{pH}$ up to $12 \mathrm{~h}$ first and then transferred into upper small intestinal $\mathrm{pH}$, lower small intestinal $\mathrm{pH}$, then colonic $\mathrm{pH}$. The coating remained
(A)

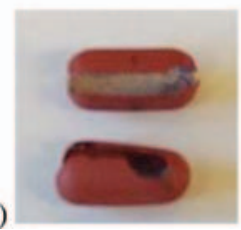

(B)

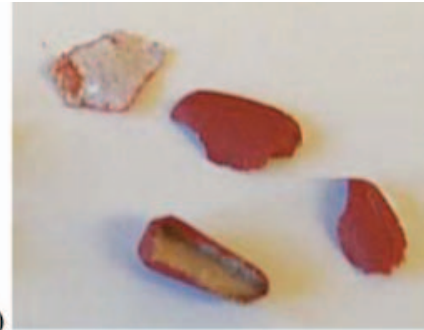

Figure 9. Eudragit $S$ coats retrieved $(A)$ at the end of $\mathrm{pH} 6.5$ after being through gastric and upper small intestinal $\mathrm{pH}$ and $(\mathrm{B})$ at the end of $\mathrm{pH} 7.2$ after being through gastric, upper and lower small intestinal $\mathrm{pH}$.

intact in gastric $\mathrm{pH}$ and upper small intestinal $\mathrm{pH}$ with one exception. After the tablet was at $\mathrm{pH} 2.75$ for $12 \mathrm{~h}$ and then transferred to $\mathrm{pH} 6.5$, it released mesalamine as early as $1 \mathrm{~h}(17.1 \%)$. The release was not because the Eudragit $\mathrm{S}$ coat dissolved in the solution, but because a slit developed in the coat. The remaining wet powder with the coat was retrieved from the dissolution vessel and photographed (Figure 9). After being through the gastric phase for $12 \mathrm{~h}$ and upper small intestinal $\mathrm{pH}$ for $3 \mathrm{~h}$, the other four tablets at $\mathrm{pH} 6.5$ also developed a slit, and drug release occurred from this opening. The amount and percentage of drug release depended on the size, shape, and position of the slit, and whether it faced upward for a long time or downward during dissolution testing (Figure 10). When the $\mathrm{pH}$ was increased from $\mathrm{pH} 6.5$ to 7.2 , the Eudragit $\mathrm{S}$ coat dissolved.

\section{SUMMARY}

The USP dissolution method for mesalamine reflects several drawbacks: (1) gastrointestinal transit times are not reflected in the USP methods for mesalamine capsules, (2) tablets are removed from vessels to change dissolution medium, and (3) neither USP method has been adopted to compare different formulations together. With the newly developed dissolution method, the experiment is easy to conduct in the lab since the tablet or capsule beads remain in the same vessel. The dissolution kinetic parameters (performance) of the extended-release and delayed-release mesalamine dosage forms can be easily
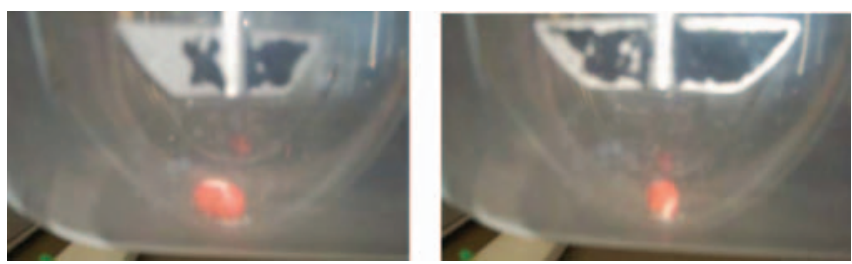

Figure 10. Slit formation in Asacol tablets in pH 6.5 medium after exposure to the gastric phase for $12 \mathrm{~h}$ and upper small intestinal $\mathrm{pH}$ for $3 \mathrm{~h}$. Dose dumping varied by the duration of the split faced up or down during dissolution. 
compared in this proposed approach. In Pentasa, the extended-release capsule, mesalamine dissolution is sensitive to low $\mathrm{pH}$. It is soluble in simulated stomach fluid in either fasted or fed condition (the release was $46.1 \%$ at $\mathrm{pH} 1.4$ for $2 \mathrm{~h}$ vs. $34.2 \%$ at $\mathrm{pH} 2.0$ for $5 \mathrm{~h}$ ). The Eudragit $\mathrm{S}$ coat of an Asacol tablet does not dissolve at $\mathrm{pH} 6.5$ until $7 \mathrm{~h}$ of continuous exposure, but may dissolve at $\mathrm{pH} 6.5$ as early as $1 \mathrm{~h}$ if the tablet has been in gastric $\mathrm{pH}$ for $12 \mathrm{~h}$ first. All tablets develop a slit in the coat in $\mathrm{pH} 6.5$ medium after being in gastric $\mathrm{pH}$ for $12 \mathrm{~h}$ and upper small intestinal $\mathrm{pH}$ for $3 \mathrm{~h}$, although the coat does not dissolve in this $\mathrm{pH}$. Based on the dissolution finding, patients with inflammatory bowel disease are advised not to take Asacol tablets with an extremely heavy meal to avoid mesalamine being released before reaching the targeted site.

\section{REFERENCES}

1. Hardman, J.G.; Limbird, L. E.; Gilman, A. G. Goodman and Gilman's The Pharmacological Basis of Therapeutics; McGraw-Hill: New York, 2001; pp 1048-1050.

2. Martin, A. N. Diffusion and Dissolution. In Physical Pharmacy: Physical Chemical Principles in the Pharmaceutical Sciences, 4th ed.; Lippincott Williams \& Wilkins: Philadelphia, 1993; pp 335-336.

3. Troy, D. B. Remington: the Science and Practice of Pharmacy; Lippincott Williams \& Wilkins: Philadelphia, 2001; p 654.
4. United States Pharmacopeia and National Formulary USP 30-NF 25; The United States Pharmacopeial Convention, Inc.: Rockville, MD, 2007; pp 1220-1223.

5. Davis, S. S., Hardy J. G., Taylor M. J., Whalley D. R. and Wilson C.G., The effect of food on the gastrointestinal transit of pellets and an osmotic device (Osmet). Int. J. Pharm. 1984, 21 (3), 331-340.

6. French, D. L.; Mauger, J.W. Evaluation of the Physicochemical Properties and Dissolution Characteristics of Mesalamine: Relevance to Controlled Intestinal Drug Delivery. Pharm. Res. 1993, $10(9), 1285-1290$.

7. Kibbe, A. H. Handbook of Pharmaceutical Excipients, 3rd ed.; American Pharmaceutical Association: Washington, DC, 2000; $p 401$.

8. Ungell, A.-L.; Abrahamsson, B. Biopharmaceutical Support in Candidate Drug Selection. In Pharmaceutical Preformulation and Formulation; Gibson, M., Ed.; Interpharm/CRC: Boca Raton, FL, 2004; p 108.

9. Washington, N.; Washington, C.; Wilson, C.G. Physiological Pharmaceutics: Barriers to Drug Absorption; Taylor and Francis: New York, 2001; p 149.

10. Avdeef, A. Physicochemical Profiling (Permeability, Solubility, Charge State). Curr. Topics Med.Chem. 2001, 1,277-351.

11. Budavari, S., O'Neil, M. J., Smith, A., Heckelman, P. E., Eds. The Merck Index, 13th ed.; Merck \& Co.: Rahway, NJ, 2001; p 5927. 